\section{Cold Treatments, Photoperiod, and Forcing Temperature Influence Flowering of Lavandula angustifolia}

\author{
Catherine M. Whitman', Royal D. Heins², Arthur C. Cameron ${ }^{2}$, and \\ William H. Carlson ${ }^{2}$ \\ Department of Horticulture, Michigan State University, East Lansing, \\ MI 48824
}

Additional index words. herbaceous perennial, lavender, long-day plant, vernalization

\begin{abstract}
The influence of cold treatments and photoperiod on flowering of 8- to 11-node and 18- to 23-node Lavandula angustifolia Mill. 'Munstead' plants from 128-cell (10-mL cell volume; $P 1)$ and 50 -cell $(85-\mathrm{mL}$ cell volume; $P 2)$ trays, respectively, was determined. Plants were stored at $5{ }^{\circ} \mathrm{C}$ for $0,5,10$, or 15 weeks, then forced under a 9-h photoperiod (SD), or under a 4-h night-interruption (NI) (2200 to $0200 \mathrm{HR})$ photoperiod at $20{ }^{\circ} \mathrm{C}$. Percentage of plants flowering, time to flower, and plant appearance were evaluated. Increasing duration of cold treatment was associated with an increase in flowering percentage in plants from both cell sizes. More plants flowered under NI than SD except in $P 2$ cooled for 15 weeks, where all plants flowered. Average time to visible bud (VB) and to opening of the first flower (FLW) generally decreased with increasing duration of cold treatment. Inflorescence count in $\mathbf{P 2}$ plants increased with increasing duration of cold treatment. To determine the relationship between forcing temperature and time to flower in L. angustifolia 'Munstead', three sizes of plants were exposed to $5^{\circ} \mathrm{C}$ for 13 weeks and then forced under a 4-h NI (2200 to $0200 \mathrm{HR})$ at $15,18,21,24$, or $27^{\circ} \mathrm{C}$. Plants generally flowered more quickly at higher temperatures, time to FLW decreasing from 77, 71, and 60 days at $\approx 15.6^{\circ} \mathrm{C}$ to 46,40 , and 36 days at $\approx 26^{\circ} \mathrm{C}$ for $\mathrm{P} 1, \mathrm{P2}$, and $5.5-\mathrm{cm}(190-\mathrm{mL}$ pot volume) (P3) plants, respectively. Generally, P1 plants flowered 5 to 10 days later than P2, and $\mathrm{P2}$ flowered 5 to 10 days later than P3.
\end{abstract}

Lavandula angustifolia is native to the Mediterranean region and is cultivated for its aromatic oil, which is used in perfumery, and as an ornamental for its purple flowers and attractive grey-green foliage (Liberty Hyde Bailey Hortorium, 1976). It is hardy in USDA zones 5 to 9 (Ball, 1991). Botanically, $L$. angustifolia is considered a shrub (Liberty Hyde Bailey Hortorium, 1976), but is commonly produced and marketed as a herbaceous perennial (Ball, 1991). Like most herbaceous perennials in North America, $L$. angustifolia is traditionally produced outdoors and is not in bloom in the spring when the majority of garden plants are sold. Since consumers prefer to purchase plants in flower, producers are interested in understanding the flowering requirements of this species.

Exposure to a period of low temperature modifies plant development and flowering in many species (Roberts and Summerfield, 1987). Some species of herbaceous perennials

Received for publication 7 Mar. 1996. Accepted for publication 19 July 1996. We gratefully acknowledge funding by the Michigan Agricultural Experiment Station, Henry Mast Greenhouses, and other greenhouse growers supportive of Michigan State Univ. floricultural research. The cost of publishing this paper was defrayed in part by the payment of page charges. Under postal regulations, this paper therefore must be hereby marked advertisement solely to indicate this fact.

${ }^{1}$ Former Graduate Student.

${ }^{2}$ Professor. require a cold treatment for subsequent flowering, while in others, low temperature hastens or improves uniformity of flowering (Iversen and Weiler, 1994). We have been unable to find information in the literature on the response of L. angustifolia to cold treatments. In preliminary experiments, we found that $L$. angustifolia seedlings required low-temperature exposure for subsequent flowering in the greenhouse, and that older seedlings were more sensitive to cold treatment (unpublished data).

A requirement for a period of low temperature frequently is coupled with a photoperiodic requirement, generally for long days, so photoperiods exceeding a certain minimum length either are required for flowering or hasten flowering (Roberts and Summerfield, 1987). In preliminary experiments, cooled $L$. angustifolia plants exhibited a facultative response to long days (unpublished data).

Production time for any crop is related to temperature provided during forcing. Most biological processes, such as flowering, proceed more quickly as temperature rises until a species-specific optimum is reached. At temperatures above optimum, development is delayed or ceases. Temperatures that produce most-rapid flowering may not result in the most attractive plants. We were unable to find any recommended temperatures for production of L. angustifolia as a flowering plant, but for greenhouse production as an herb, 15 to 18 ${ }^{\circ} \mathrm{C}$ has been suggested, although experimental evidence was not presented (Laskey, 1991).

The objectives of our study were to deter- mine the influence of plant size, cold treatment, and photoperiod on flowering and to determine the effect of forcing temperature on time to flower. Percentage of plants flowering, time to flower, and plant appearance were evaluated.

\section{Materials and Methods}

General. Plants were grown in a commercial soilless medium containing composted pine bark, horticultural vermiculite, Canadian sphagnum peat, processed bark ash, and washed sand (MetroMix 510; Scotts-Sierra Horticultural Products Co., Marysville, Ohio). Plants were top-watered as necessary with $7 \mathrm{~mm} \mathrm{~N}$ from a $20 \mathrm{~N}-4.4 \mathrm{P}-16.6 \mathrm{~K}$ all-purpose watersoluble fertilizer, (Peter's Professional Peatlite Special; Grace-Sierra Horticultural Products Co., Milpitas, Calif.). Supplemental lighting (high-pressure sodium providing $\approx 50$ $\mu \mathrm{mol} \cdot \mathrm{m}^{-2} \cdot \mathrm{s}^{-1}$ at plant level) was initiated at 200 $\mu \mathrm{mol} \cdot \mathrm{m}^{-2} \cdot \mathrm{s}^{-1}$ ambient photosynthetic photon flux (PPF) and terminated when PPF exceeded $400 \mu \mathrm{mol} \cdot \mathrm{m}^{-2} \cdot \mathrm{s}^{-1}$.

Plants were exposed to cold treatments in a $5 \pm 0.5^{\circ} \mathrm{C}$ cooler illuminated for $9 \mathrm{~h} \cdot \mathrm{day}^{-1}$ with cool-white fluorescent lamps (VHOF96T12; Philips, Bloomfield, N.J.) at $\approx 10 \mu \mathrm{mol} \cdot \mathrm{m}^{-2} \cdot \mathrm{s}^{-1}$, and were watered with well water $(340 \mathrm{mg}$ $\left.\mathrm{CaCO}_{3} / \mathrm{L}\right)$ acidified $\left(93 \% \mathrm{H}_{2} \mathrm{SO}_{4}\right)$ to a titratable alkalinity of $100 \mathrm{mg} \mathrm{CaCO}_{3} / \mathrm{L}$.

Cold treatments and photoperiod (Expt. 1). Two plug sizes were tested. Seedlings with 8 to 11 nodes growing in 128-cell trays (10$\mathrm{mL}$ cell volume; $\mathrm{P} 1$ ) and seedlings with 18 to 23 nodes in 50-cell trays ( $85-\mathrm{mL}$ cell volume; P2) were received from a commercial producer on 27 Oct. 1994. Twenty plants of each size were removed from the plug tray, thinned to a single plant per cell (singulated), and transplanted. The seedlings in P1 were transplanted into $10 \times 9-\mathrm{cm}$ containers $(470-\mathrm{mL})$ and those from P2 into $16 \times 16-\mathrm{cm}(2.2-\mathrm{L})$ containers. Plants were placed in the greenhouse at $20^{\circ} \mathrm{C}$. Ten plants of each size group were placed under a 9-h photoperiod (SD) and 10 under a 9-h photoperiod with a 4-h night interruption (NI) from 2200 to $0200 \mathrm{HR}$. The NI was supplied by $60-\mathrm{W}$ incandescent lamps at 3 to $5 \mu \mathrm{mol} \cdot \mathrm{m}^{-2} \cdot \mathrm{s}^{-1}$ as measured at plant height by a LI-COR quantum sensor model LI-189 (LI-COR, Lincoln, Neb.). Black cloth was pulled at $1700 \mathrm{HR}$ and opened at $0800 \mathrm{HR}$ on all benches. Remaining plugs were placed in the cooler. Twenty plugs of each size group were removed from the cooler at 5-week intervals and treated as described above. Dates of the first visible bud (VB) (when the inflorescence was $\approx 2 \mathrm{~mm}$ long) and of first open flower (FLW) were recorded for each plant, and days from transplant to VB and FLW were calculated. At flowering, total plant height, number of visible inflorescences, and number of nodes on the main stem were determined.

Air temperatures on each bench were monitored every $10 \mathrm{~s}$ with two 36 -gauge $(0.127 \mathrm{~mm}$ in diameter) thermocouples connected to a CR10 datalogger (Campbell Scientific, Logan, Utah). Nighttime air under black cloth on solid aluminum benches can be $3.5^{\circ} \mathrm{C}$ cooler 
than greenhouse air temperatures because of radiant heat loss to the greenhouse glazing material (Heins and Faust, 1994). To provide uniform temperature conditions, the datalogger controlled a 1500-W electric heater under each bench, which provided supplemental heat as needed throughout the night. The actual daily air mean throughout the course of the experiment was $20.4^{\circ} \mathrm{C}$. The maximum difference in actual daily air mean between any two treat-

Forcing temperature (Expt. 2). Three plant sizes were tested. Seven- to nine-node seedlings in P1 and 19 to 23 node seedlings in P2 were received from a commercial producer 27 Oct. 1994 . They were placed in a $5{ }^{\circ} \mathrm{C}$ cooler for 13 weeks until 21 Jan. 1995, when they were singulated and transplanted. Plants from P1 were transplanted into $10 \times 9-\mathrm{cm}$ containers $(470-\mathrm{mL})$, and those from $\mathrm{P} 2$ into $13-\mathrm{cm}$ square containers (1.1-L). Ten plants of each size were placed in each of five greenhouses set to $15,18,21,24$, or $27^{\circ} \mathrm{C}$. Plants growing in $5.5 \times 9-\mathrm{cm}$ pots $(190-\mathrm{mL}$ volume; $\mathrm{P} 3)$ were received on 17 Jan. 1995, transplanted into 16 $\times 16-\mathrm{cm}(2.2-\mathrm{L})$ containers, and 10 were placed in each of the treatment zones on 4 Feb. 1995. Plants received natural daylengths with a 4-h NI from 2200 to $0200 \mathrm{HR}$, provided by highpressure sodium lamps that delivered $\approx 90$ $\mu \mathrm{mol} \cdot \mathrm{m}^{-2} \cdot \mathrm{s}^{-1}$. Data were recorded as described for Expt. 1.

Temperatures in each greenhouse were controlled with a Priva environmental computer (model CD750; Priva, De Lier, Holments throughout the experiment was $0.7^{\circ} \mathrm{C}$.

land). Actual air temperatures were recorded every 15 min by a CR-10 datalogger. Actual average daily air temperatures were determined and used in all calculations.

\section{Results}

Cold treatments and photoperiod. Percentage of plants from P1 that flowered did not reach 100 in any treatment (Fig. 1). Increasing durations of cold treatment were associated with an increase in flowering percentage in $\mathrm{P} 1$ and $\mathrm{P} 2$ plants. The percentage of plants flowering for both plant sizes tested was higher under NI than SD, except in P2 cooled for 15 weeks, where all plants flowered.

Plants cooled for 5 weeks reached VB and FLW $\approx 30$ days more rapidly than noncooled plants (Fig. 1). Cold treatments of 10 or 15 weeks further reduced mean time to VB and FLW by $\approx 10$ days.

Plants of $\mathrm{P} 1$ that flowered produced one to two inflorescences in all treatments (Fig. 2). The average number of inflorescences on P2 plants increased with increasing durations of cold treatment.

The final node count and height in P1 under NI were similar whether plants were cooled for 10 or 15 weeks (Fig. 2). Final node count and height in P2 were not affected by cold treatments.

Forcing temperature. All plants flowered at all temperatures, except for those from $\mathrm{P} 1$ at $\approx 26^{\circ} \mathrm{C}$ (40\% flowered) and $23^{\circ} \mathrm{C}(70 \%$ flowered). Time to FLW decreased as forcing
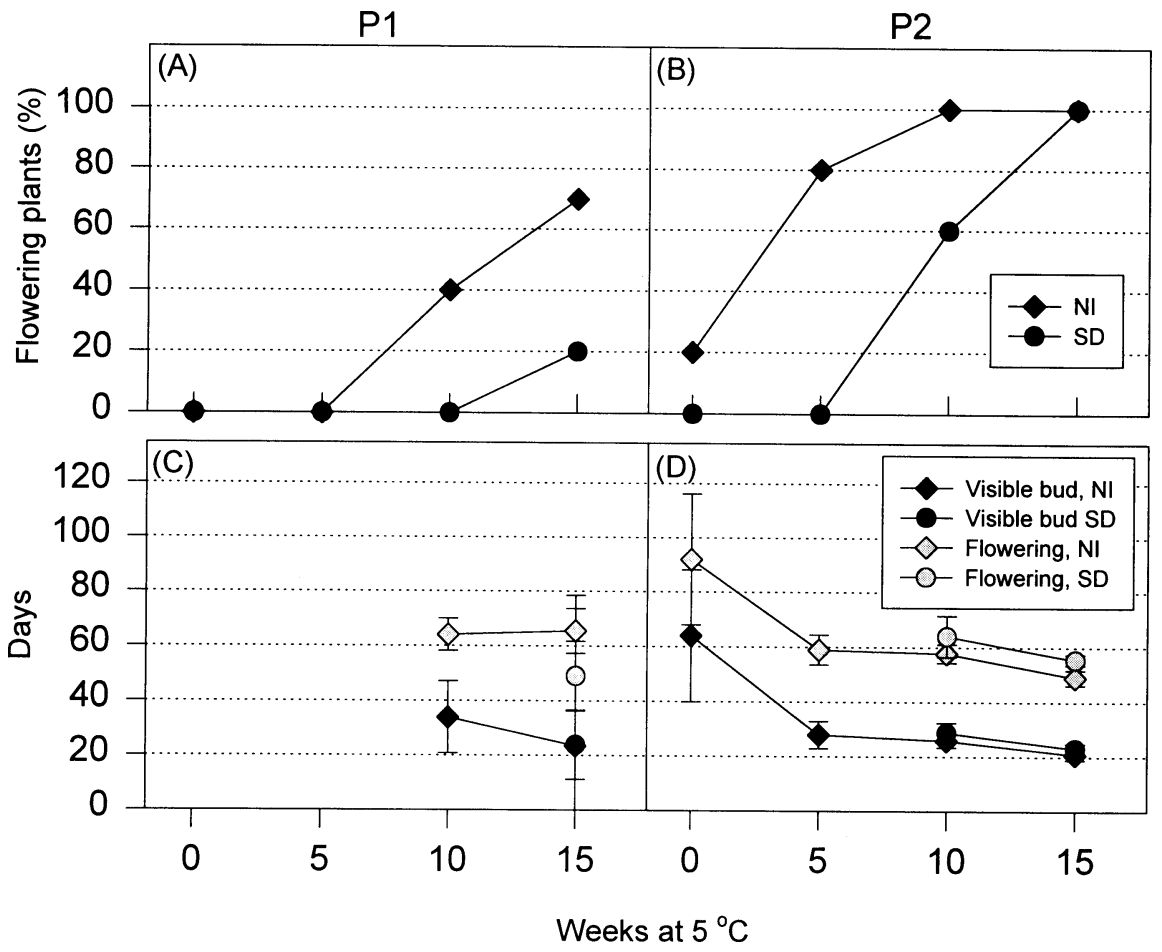

Fig. 1. Influence of cold treatments on flowering of L. angustifolia 'Munstead' forced in a $20^{\circ} \mathrm{C}$ greenhouse under either a 9-h photoperiod (SD), or a 9-h photoperiod with a 4-h night-interruption (NI) (2200 to 0200 $\mathrm{HR}$ ) photoperiod. (A) and (B) show flowering percentage for plants from 128-cell trays (8 to 11 nodes, P1) and from 50-cell trays (18 to 23 nodes, P2), respectively, within the 120-day duration of the experiment. (C) and (D) show time to visible bud and flower for P1 and P2, respectively. Error bars in (C) and (D) represent 95\% confidence intervals. temperature increased from $\approx 16^{\circ} \mathrm{C}$ to $\approx 21^{\circ} \mathrm{C}$, but further increases had little effect (Fig. 3). Time to FLW at $\approx 16^{\circ} \mathrm{C}$ averaged 69 days, and at $\approx 26^{\circ} \mathrm{C}, 41$ days. Under all forcing temperatures, $\mathrm{P} 1$ plants flowered 5 to 10 days later than $\mathrm{P} 2$, and $\mathrm{P} 2$ flowered 5 to 10 days later than $\mathrm{P} 3$.

Larger initial plant size resulted in a higher average inflorescence count per plant (Fig. 4). Increasing forcing temperature had little effect on inflorescence count on P1 and P2 plants, but was associated with a decreasing number of inflorescences for $\mathrm{P} 3$ plants. Plants from $\mathrm{P} 1, \mathrm{P} 2$, and $\mathrm{P} 3$ grew 5, 6, and $12 \mathrm{~cm}$ taller, respectively, when plants were forced at $\approx 15$ ${ }^{\circ} \mathrm{C}$ than at $\approx 26^{\circ} \mathrm{C}$. The $\mathrm{P} 3$ plants were pruned before shipment, resulting in a final plant height below that of $\mathrm{P} 2$ plants.

\section{Discussion}

Many biennials and perennials must attain a certain size before they are capable of floral induction. Juvenility is defined as an early developmental phase during which a plant is insensitive to conditions that later promote flower initiation (Bernier et al., 1981). A juvenile phase has been described in several herbaceous perennials including some cultivars of Aquilegia $\times$ hybrida Sims. (Shedron and Weiler, 1982), and Heuchera sanguinea Engelm. (Yuan, 1995). A juvenile phase appears to exist in L. angustifolia 'Munstead', but its duration could not be determined from these experiments. What these experiments did show is that plant size influences the flowering response of L. angustifolia 'Munstead'. Plants with 8 to 11 nodes required a longer cold treatment to induce flowering than those with 18 to 23 nodes. Because $100 \%$ of 18 - to $23-$ node P2 plants flowered in Expt. 2, and because flowering for P1 plants in Expt. 1 did not reach $100 \%$ in any treatment, but $100 \%$ of $\mathrm{P} 1$ plants flowered in some treatments in Expt. 2 (Figs. 1 and 3), the juvenile phase in $L$. angustifolia 'Munstead' appears to end after plants have about 8 to 11 nodes.

Low temperatures are required for flowering of many herbaceous perennials. The requirement for cold differs among species, and can often be categorized by the relationship between exposure to cold and time of floral initiation. Some species of herbaceous perennials require a cold treatment for 1 ) further development of existing dormant flower buds; 2) in others, floral bud initiation occurs during exposure to low temperatures; and 3) in some cases, low temperatures hasten or are required for subsequent initiation and development of floral primordia. For species in the third category, floral primordia are not initiated until after the return of warmer temperatures, and in many species initiation will not occur until photoperiodic requirements are met as well (Chouard, 1960). Our experiments show that exposure to a period of low temperatures is the primary factor promoting flowering in $L$. angustifolia 'Munstead'. Increasing durations at $5{ }^{\circ} \mathrm{C}$ were associated with an increase in flowering percentage and number of inflorescences, and a decrease in time to flower (Figs. 1 and 2). Vegetative growth emerged from the 
P1
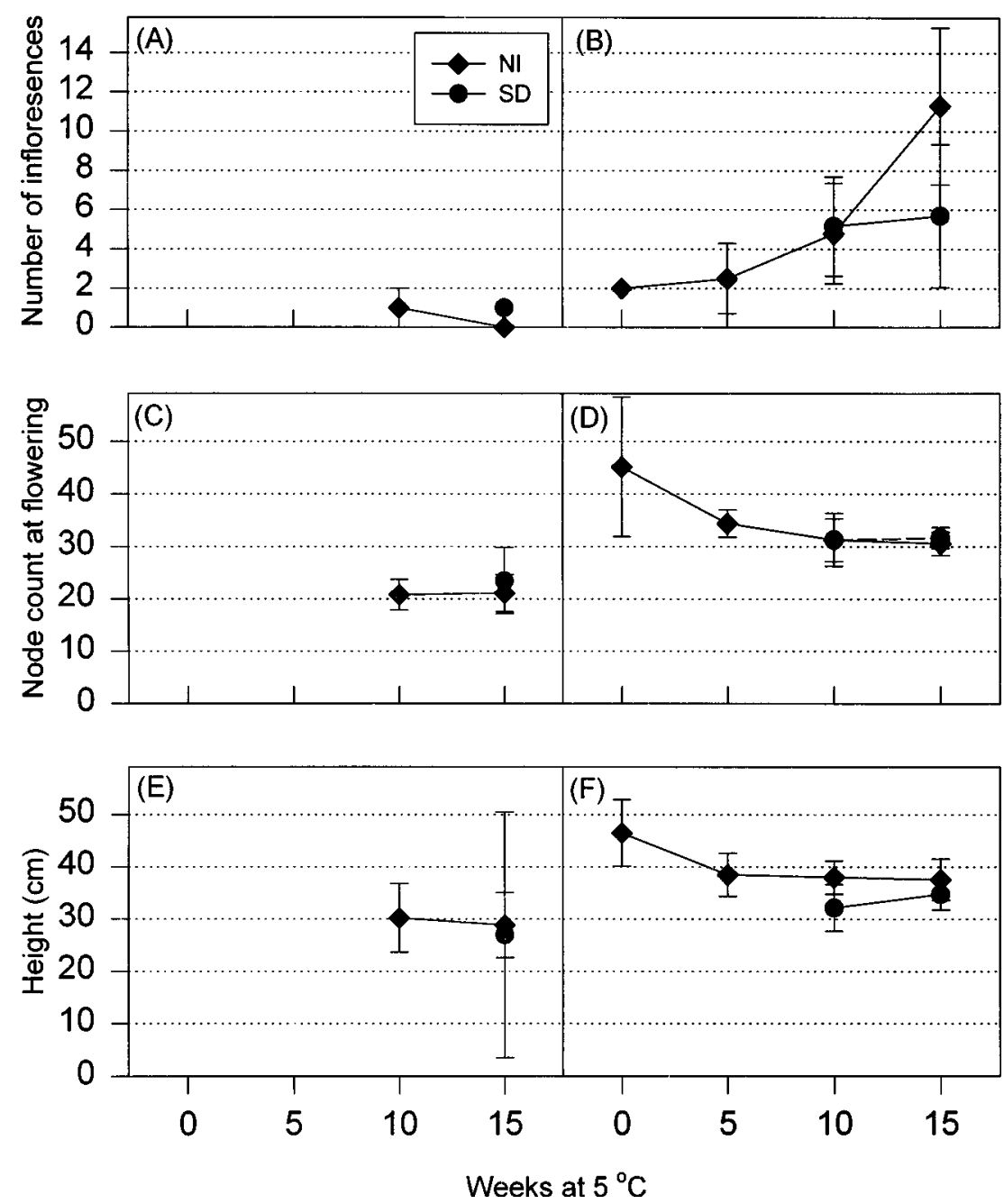

Fig. 2. Influence of cold treatments on flowering of L. angustifolia 'Munstead' forced in a $20^{\circ} \mathrm{C}$ greenhouse under either a 9-h photoperiod (SD), or a 9-h photoperiod with a 4-h night-interruption (NI) (2200 to 0200 HR) photoperiod. (A) and (B) represent number of inflorescences visible per plant at the time of first flower opening for plants from 128-cell trays (8 to 11 nodes, P1) and from 50-cell trays (18 to 23 nodes, P2), respectively. (C) and (D) show number of nodes present on the main stem at flowering for P1 and $\mathrm{P} 2$, respectively. (E) and (F) are total plant height at flowering for P1 and P2, respectively. Error bars represent $95 \%$ confidence intervals. apical meristem, but flowering was absent on L. angustifolia 'Munstead' plants that were not exposed to low temperatures. Since this plant has a terminal inflorescence, it is unlikely that flower buds were present before cold treatments. While low temperatures clearly promote flower induction of $L$. angustifolia 'Munstead', we did not determine in these experiments whether initiation occurs during or after cold treatments.

When P2 plants were cooled for 10 or 15 weeks, most flowered when forced under SD. Extended exposure to $5{ }^{\circ} \mathrm{C}$ apparently eliminated any subsequent photoperiodic requirement for flowering of L. angustifolia 'Munstead'. A similar response has been found in some other herbaceous perennials (Buxton and Mohr, 1969; Iversen, 1989; Lopes and Weiler, 1977; Shedron, 1980).

Forcing temperatures have a significant effect on rates of development in all plants. Optimum temperature ranges vary within and between species and are related to climatic origin (Roberts and Summerfield, 1987). Fewer L. angustifolia 'Munstead' flowered when forced at 23 and $26{ }^{\circ} \mathrm{C}$ than when forced at lower temperatures, suggesting that $23^{\circ} \mathrm{C}$ is near the optimum for this species. Alternatively, temperatures $\geq 23{ }^{\circ} \mathrm{C}$ may have devernalized the plants. Inflorescences were similar in appearance at all temperatures tested.

Initial plant size influenced time to VB and FLW at all forcing temperatures. The P3 plants were pruned before shipment, yet flowered 5 to 10 days before $\mathrm{P} 2$. The $\mathrm{P} 2$ plants flowered 5 to 10 days before $\mathrm{P} 1$ plants. The larger plants apparently were at a more advanced physiological stage at the start of forcing. Also, fewer P1 plants flowered at $\geq 23{ }^{\circ} \mathrm{C}$ than at lower temperatures, but all $\mathrm{P} 2$ and $\mathrm{P} 3$ plants flowered at all temperatures tested.

Regrowth of the pruned P3 plants used in this experiment was compact, uniform, and attractive. P1 and P2 plants were not pruned, and were sometimes weak and uneven in appearance. Although not specifically tested in this work, our observations suggest that prun-

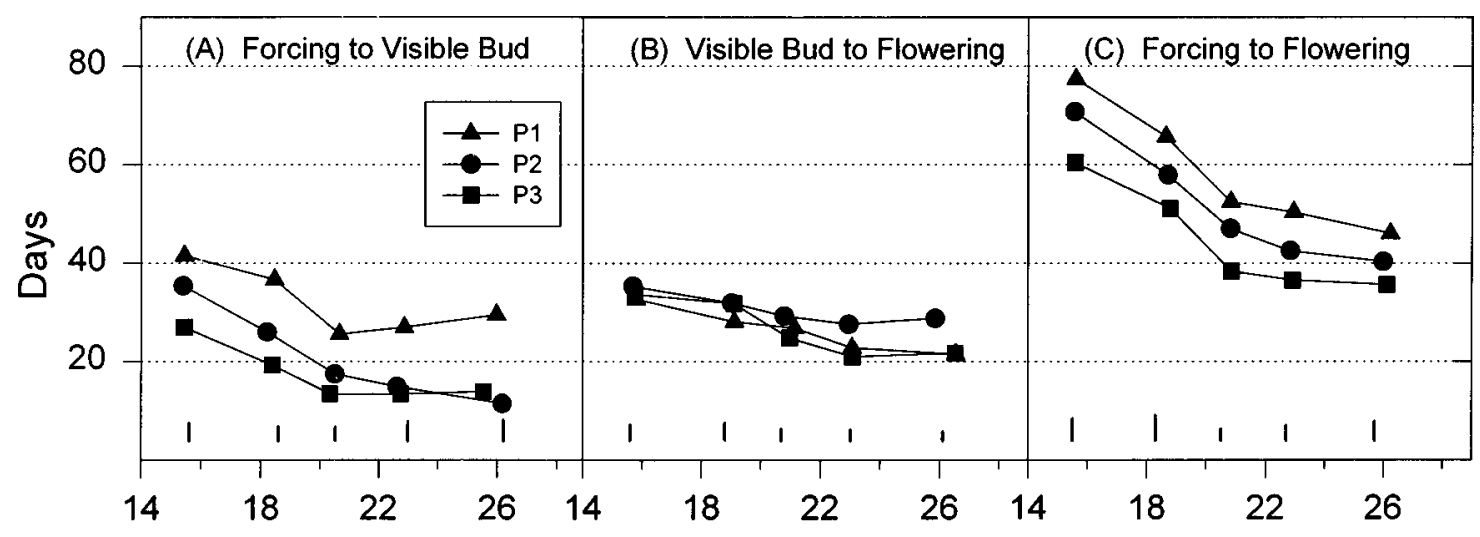

Temperature $\left({ }^{\circ} \mathrm{C}\right)$

Fig. 3. Influence of forcing temperature on flowering of L. angustifolia 'Munstead' plants from 128-cell trays (P1), 50-cell trays (P2), and 5.5-cm pots (P3). Each $\operatorname{symbol}(\boldsymbol{\Lambda}, \boldsymbol{\bullet}$, or $)$ represents the mean of 10 plants except for $\mathrm{P} 1$ at $23{ }^{\circ} \mathrm{C}$ (seven flowered) and $\approx 26^{\circ} \mathrm{C}$ (four flowered). Vertical bars represent least significant differences (LSD) between plug sizes at each forcing temperature. 


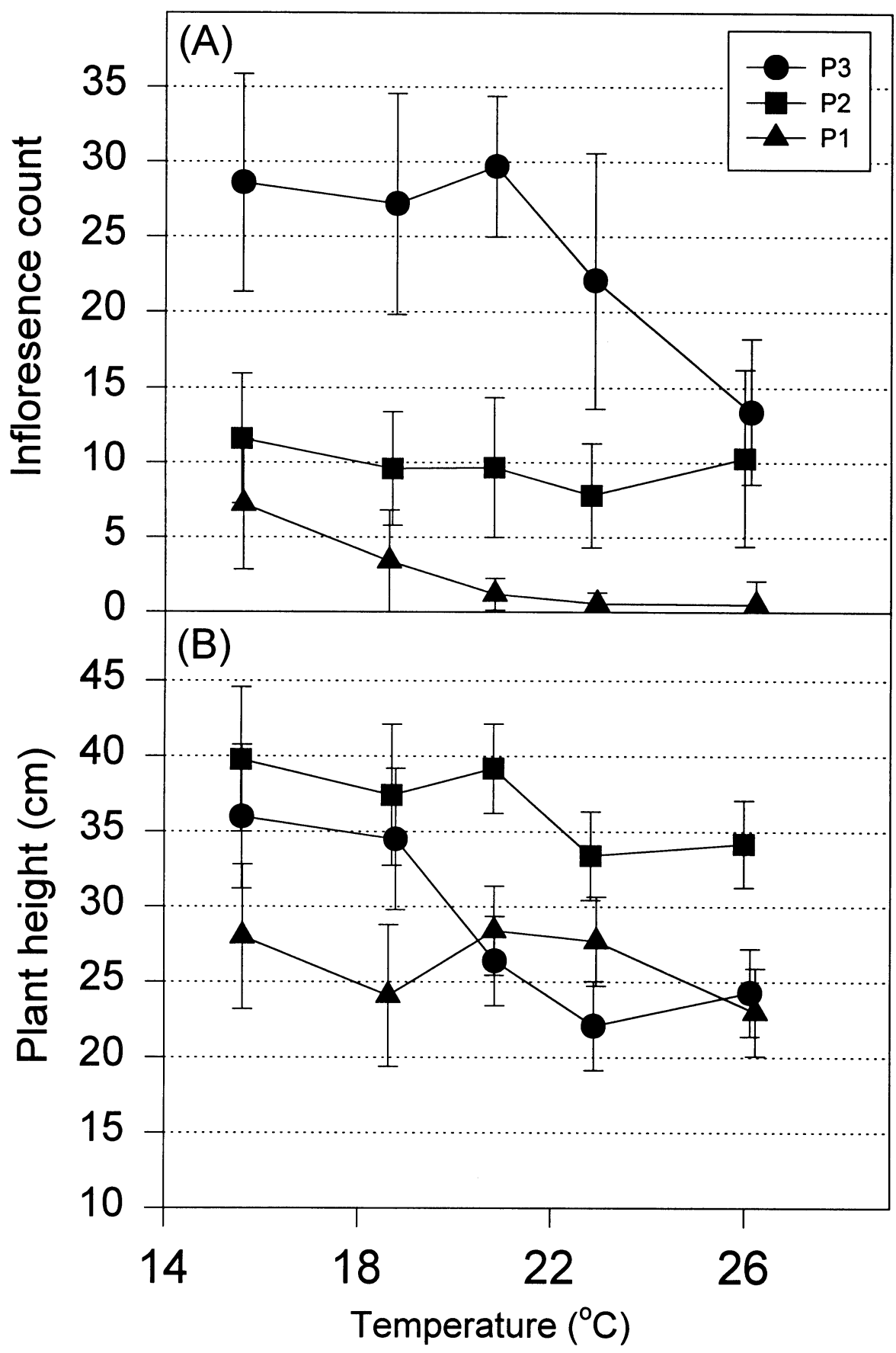

Fig. 4. Influence of forcing temperature on (A) number of inflorescences and (B) total plant height in $L$. angustifolia 'Munstead'plants from 128-cell trays (P1), 50-cell trays (P2), and 5.5-cm pots (P3). Each $\operatorname{symbol}(\boldsymbol{\Lambda}, \boldsymbol{O}$, or $\boldsymbol{\square})$ represents the mean of 10 plants, except for $\mathrm{P} 1$ at $23{ }^{\circ} \mathrm{C}$ and $\approx 26{ }^{\circ} \mathrm{C}$ where the symbols represent the mean of seven and four plants, respectively. Error bars represent $95 \%$ confidence intervals. ing or pinching prior to cooling and forcing may be beneficial when forcing other sizes of L. angustifolia 'Munstead' as flowering plants.

In conclusion, recommendations for bringing L. angustifolia 'Munstead' to flower for commercial production include using initial plant material with more than 11 nodes, and providing a minimum of 10 weeks of $5{ }^{\circ} \mathrm{C}$. Flower count may be increased slightly if the plants subsequently are forced under a 4-h NI. Cooled plants with 18 to 23 nodes forced under NI will flower in $\approx 7$ weeks at $20^{\circ} \mathrm{C}$.

\section{Literature Cited}

Ball, V. 1991. Perennials, p. 677-689. In: V. Ball, (ed.). Ball red book. 15th ed. Ball Publishing, Chicago.

Bernier, G., J. Kinet, and R. Sachs. 1981. The physiology of flowering, vol. 2. CRC Press, Boca Raton, Fla. p. 106-115.

Buxton, J. and H. Mohr. 1969. The effect of vernalization and photoperiod on flowering of tall bearded irises. HortScience 4:53-55.

Chouard, P. 1960. Vernalization and its relations to dormancy. Annu. Rev. Plant Physiol. 11:191238.

Heins, R. and J. Faust. 1994. Radiant cooling leads to cooler temperatures under black cloth. HortScience 29:503. (Abstr.)

Iversen, R. 1989. Greenhouse forcing of herbaceous garden perennials. PhD Diss., Cornell Univ., Ithaca, N.Y.

Iversen, R. and T. Weiler. 1994. Strategies to force flowering of six herbaceous garden perennials. HortTechnology 4:61-65.

Laskey, M. 1991. Herbs, p. 577-581. In: V. Ball (ed.). Ball red book. 15th ed. Ball Publishing, Chicago.

Liberty Hyde Bailey Hortorium. 1976. Hortus third. Macmillan, New York.

Lopes, L. and T. Weiler. 1977. Light and temperature effects on the growth and flowering of Dicentra spectabilis (L.) Lem. J. Amer. Soc. Hort. Sci. 102:388-390.

Roberts, E. and R. Summerfield. 1987. Measurement and prediction of flowering in annual crops, p. 17-51. In: J.G. Atherton (ed.). Manipulation of flowering. Butterworth's, London.

Shedron, K. 1980. Regulation of growth and flowering of four herbaceous perennials: Aquilegia Xhybrida Sims, Aurinia saxatilis (L.) Desv., Chrysanthemum Xsuperbum Bergmans, and Lupinus spp. 'Russell'. MS Thesis, Purdue Univ., Lafayette, La.

Shedron, K. and T. Weiler. 1982. Regulation of growth and flowering in Aquilegia $\times$ hybrida Sims. J. Amer. Soc. Hort. Sci. 107:878-882.

Yuan, M. 1995. Effect of juvenility, temperature, and cultural practices on flowering of five herbaceous perennials. MS Thesis, Michigan State Univ., E. Lansing. 